\title{
ANALYSIS OF BUSINESS FEASIBILITY OF Bio Solid Rubber (BSR) AS A CONTENT OF RUBBER VIBRATION
}

\section{ANALISIS KELAYAKAN BISNIS USAHA Bio Solid Rubber (BSR) SEBAGAI PENGENTAL GETAH KARET}

\author{
Anissa ${ }^{1)}$, Adelia Anggraini ${ }^{1)}$, Sri Maulana Putri ${ }^{1)}$, Yudha Andriansyah Putra ${ }^{2)}$ \\ 1) Jurusan Agribisnis, Fakultas Pertanian Universitas Muhammadiyah Sumatera Utara \\ 2) Dosen Agribisnis,Fakultas Pertanian Universitas Muhammadiyah Sumatera Utara. \\ Jalan Kapten Mukhtar Basri No 3 Medan \\ Email: anissa99112@gmail,com
}

\begin{abstract}
Rubber plants have a big role in Indonesia's economic life. Many people live by relying on rubber plantations as their business commodities and especially for those living in the countryside. The fruit of the Mengkudu is one of the plants that is rich in benefits. In addition to the medical world, the Mengkudu juice can also be utilized as one of the alternative ingredients for the use of latex acid replacement formiat. Acid content in the fruit of the mengkudu when mixed with latex, it will form coagulants. The coagulant is used in the form of a mengkudu fruit. The juice of the mengkudu that is used is the fruit juice of ripe mengkudu and juice Mengkudu peram. Coagulation using a yam cider starch is a natural-based coagulation that is safe for farmers despite the cyanide content (HCN) Business feasibility study is required to see a description of the feasibility or unworthiness of the business that will Done. The research aims to see if the BSR business as a rubber cilier is feasible or not to do. Every aspect that is said to be worthy should have a certain standard of value, but judgment is not only done in one aspect. The assessment for determining eligibility should be based on several aspects. The method used in this research is the method of SWOT analysis (strength, weaknesses, opportunities, threats), economic analysis of the business which includes: (Calculating the price of production, selling price, profit, and Ratio) and also using the way Marketing strategies that include: (Product strategy, pricing strategy, place strategy and also promotion strategy). From the results of the study showed that BSR business is worthy to run and has excellent prospects.
\end{abstract}

Keywords: feasibility, Rubber, Solid

\begin{abstract}
Abstrak
Tanaman karet memiliki peranan yang besar dalam kehidupan perekonomian Indonesia. Banyak masyarakat yang hidup dengan mengandalkan perkebunan karet sebagai komoditas usahanya dan khususnya bagi mereka yang tinggal di pedesaan. Buah mengkudu merupakan salah satu tanaman yang kaya akan manfaat. Selain di dunia medis sari buah mengkudu juga dapat dimanfaatkan sebagai salah satu bahan alternatif penggumpal lateks pengganti asam formiat. Kandungan asam yang terdapat dalam buah mengkudu apabila dicampurkan dengan lateks maka akan membentuk koagulan. Koagulan yang digunakan berupa sari dari buah mengkudu. Sari buah mengkudu yang digunakan adalah sari buah mengkudu matang dan sari buah mengkudu peram. Koagulasi menggunakan sari pati umbi gadung merupakan koagulasi berbahan dasar alami yang aman bagi petani walaupun memiliki kandungan sianida $(\mathrm{HCN})$ Studi kelayakan bisnis diperlukan untuk melihat deskripsi kelayakan atau ketidaklayakan bisnis yang akan dilakukan. Penelitian ini bertujuan untuk melihat apakah bisnis $B S R$ sebagai pengental karet layak atau tidak untuk dilakukak untuk dilakukan. Setiap aspek yang dikatakan layak harus memiliki standar nilai tertentu, tetapi penilaian tidak hanya dilakukan dalam satu aspek. Penilaian untuk menentukan kelayakan harus didasarkan pada beberapa aspek. Metode yang digunakan dalam penelitian ini yaitu metode analisis SWOT (strength, weaknesses, opportunities, threats), analisis ekonomi usaha yang meliputi: (menghitung Harga Pokok Produksi, Harga jual, Keuntungan, dan Ratio) dan juga menggunakan cara strategi pemasaran yang meliputi: ( Strategi Produk, Strategi Harga, Strategi Tempat dan juga Strategi Promosi). Dari hasil penelitian yang dilakukan menunjukkan bahwa bisnis BSR layak untuk dijalankan dan memiliki prospek yang sangat baik.
\end{abstract}

Kata kunci: Kelayakan usaha, karet, menyatu

\section{A. PENDAHULUAN}

Tanaman karet mulai dikenal Indonesia sejak zaman penjajahan Belanda. Di Indonesia, karet alam (Hevea brasiliensis) banyak dimanfaatkan secara luas dalam skala industri 
maupun untuk kepentingan masyarakat. Karet menjadi komoditas penting selain kelapa sawit, teh dan kakao, baik sebagai pendapatan devisa, kesempatan kerja dan pendorong pertumbuhan ekonomi sentra-sentra baru di wilayah sekitar perkebunan karet maupun pelestarian lingkungan serta sumber daya hayati. Hal ini ditunjukkan oleh jumlah petani yang terlibat dalam usaha karet alam mencapai 1,907 juta kepala keluarga sehingga banyak penduduk menggantungkan hidup dari tanaman ini (Lestari,2018)

Luas wilayah daratan Indonesia mencapai 1.922.570 $\mathrm{km}^{2}$ dan terbagi kepada 34 Provinsi dan 403 kabupaten. Salah satunya yaitu Provinsi Sumatera Utara di Kabupaten Langkat yang banyak masyarakatnya bekerja sebagai petani salah satunya adalah petani karet (Hevea brasiliensis). Melihat luas panen dan produksi yang besar,ternyata masih banyak permasalahan yang dihadapi oleh petani karet salah satunya permasalahan dalam proses pengentalan getah karet (BIG,2010)

Indonesia mempunyai potensi untuk menjadi produsen utama karet dunia walaupun saat ini masih kedua setelah Thailand, apabila berbagai permasalahan utama yang dihadapi perkebunan karet dapat diatasi dan agribisnisnya dikembangkan serta dikelola secara baik. Indonesia masih memiliki lahan potensial yang cukup besar untuk pengembangan karet terutama di Kalimantan Barat, kalimantan Tengah, Kalimantan Selatan ,Kalimantan Timur dan Papua (Sabarman,2012)

Bahan olah karet adalah lateks kebun serta gumpalan lateks kebun yang diperoleh dari pohon karet Hevea brasiliensis. Beberapa kalangan menyebut bahan olah karet bukan produksi perkebunan besar, melainkan merupakan bokar ( bahan olah karet rakyar ) karena biasanya diperoleh dari petani yang mengusahakan kebun karet. Menurut pengolahannya bahan olah karet dibagi menjadi 4 macam yaitu : (1) Lateks kebun adalah cairan getah yang didapat dari bidang sadap pohon karet. Cairan getah ini belum mengalami penggumpalan entah itu dengan tambahan atau tanpa bahan pemantap (2) Sheet angin adalah bahan olah karet yang dibuat dari lateks yang sudah disaring dan digumpalkan dengan asam semut, berupa karet sheet yang sudah digiling tetapi belum jadi (3) Slab tipis adalah bahan olah karet yang terbuat dari lateks yang sudah digumpalkan dengan asam semut (4) Lump segar adalah bahan olah karet yang bukan berasal dari gumpalan lateks kebun yang terjadi secara alamiah dalam mangkuk penampung (Risky, 2011)

Dengan harga karet seperti saat ini, banyak pelaku agribisnis yang tertarik untuk mengembangkan perkebunan karet. Peluang ini dimanfaatkan oleh perusahaan-perusahaan perkebunan baik milik negara (BUMN) serta peluang bagi usaha $B S R$ ini untuk dilakukan karena banyak masyarakat berprofesi sebagai petani dan banyak perusahaan-perusahaan milik Negara yang mengembangkan usaha karet ( Syarifa, 2014)

Berhasil tidaknya suatu perusahaan bergantung pada keberhasilan bagian pemasaran dalam meningkatkan penjualan. Penjualan merupakan ujung tombak dalam mencapai tujuan perusahaan mencari laba yang maksimal. Oleh karena itu anggaran penjualan sering disebut anggaran kunci. Anggaran penjualan merupakan dasar penyusunan anggaran lainnya dan umumnya disusun terlebih dahulu. Kesalahan dalam penyusunan anggaran penjualan akan mengakibatkan kesalahan pada anggaran yang lain. Anggaran penjualan ini meliputi data jenis produk yang dijual, volume produk yang dijual, harga produk persatuan, dan wilayah pemasaran ( Rahayu, 2011)

Berdasarkan observasi tahun 2019 di Kabupaten Langkat saat itu pada proses pengentalan/pencetakan getah karet (Hevea brasiliensis) kebanyakan petani masih menggunakan bahan kimia. Melihat dari petani di kabupaten langkat ini, penggunaan bahan kimia belum juga sepenuhnya bisa meningkatkan kualitas dan hasil yang maksimal, dimana getah karet yang mereka cetak tampilannya kurang bagus atau bisa disebut kurang merekat di tambah lagi jika di timbang berat kilonya menurun.

Berdasarkan permasalahan yang ada maka perlu untuk melakasanakan perbaikan dengan menciptakan sebuah inovasi baru yang dapat membantu menyelesaikan permasalahan petani karet ini yaitu dengan menciptakan Inovasi Baru Pengganti Bahan Kimia Dalam Proses Pengentalan Getah Karet Dengan Bahan Organik yang di beri nama BSR (Bio solid rubber) yang ramah lingkungan serta memperkecil resiko keracunan yang terjadi dalam penggunaan bahan kimia oleh petani. Dan bertujuan untuk membantu masyarakat petani karet dalam mengentalkan getah karet mereka.

BSR( Bio solid rubber) merupakan produk baru yang terbuat dari kombinasi bahan baku sederhana dan sangat mudah didapat yaitu umbi gadung dan buah mengkudu sebagai bahan untuk proses pengentalan getah karet yang baru siap dipanen.

Mengingat pati yang telah dimanfaatkan berasal dari bahan pangan, maka penelitian ini ditujukan untuk pemanfaatan pati umbi gadung. Umbi Dioscorea hispida Dennst (D. Hispida) tidak 
efisien digunakan untuk bahan pangan, akan tetapi lebih banyak digunanakan untuk bahan non pangan seperti pengental getah oleh masyarakat perkebunan karet, sebagai insektisida, dan lain-lain. Hal ini dikarenakan, umbi ini mengandung senyawa beracun Dioscorin yang bersifat toksik terhadap tubuh manusia. Mengingat potensi dan ketersediaan umbi gadung yang cukup tinggi di wilayah Indonesia, alternatif pemanfaatan pati gadung untuk meningkatkan nilai jual dan nilai guna perlu diekploitasi ke arah non pangan (Susanto 2016)

Koagulasi menggunakan sari pati umbi gadung merupakan koagulasi berbahan dasar alami yang aman bagi petani walaupun memiliki kandungan sianida ( $\mathrm{HCN})$ yang bersifat toksik namun dengan mencuci tangan setelah bersentuhan langsung atau setelah selesai menggunakan umbi gadung maka hal tersebut tidak akan berbahaya, sehingga lebih ramah lingkungan dan dapat diproduksi sendiri oleh petani secara konvensional. Pemanfaatan umbi gadung dalam penelitian ini dikarenakan keberadaannya yang banyak, tersebar dan mudah ditemukan serta secara ekonomis lebih menguntungkan sehingga dapat menurunkan biaya produksi (lestari,2018)

Dengan menggunakan pembeku yang tepat diharapkan dapat meningkatkan kualitas karet yang dihasilkan. Ketersediaan pembeku (koagulan) berkualitas dan murah menjadi prasyarat tumbuhnya industri pada sektor perkebunan karet yang maju. Pembeku yang murah membuat pelaku usaha mampu meningkatkan skala usaha dan keuntungan per satuan, sedangkan pembeku berkualitas meningkatkan konversi pembeku sehingga proses pemberian pembeku lebih efisien (Chusna,2017)

Dengan alasan harga yang mahal dan ketersediaan yang langka, masih banyak petani karet yang tidak menggunakan asam formiat sebagai bahan penggumpal. Mereka lebih cenderung memakai bahan penggumpal lain, seperti asam sulfat (H2SO4), tawas dan bahan penggumpal alami. Fakta di atas membuka peluang bagi pengembangan bahan penggumpal alternative (Hardiyanti, 2013)

tujuan strategi pemasaran barang itu sendiri yaitu: (1) Peningkatan kualitas koordinasi dalam tim pemasaran, hal ini dilakukan agar setiap anggota tim dapat bekerjasama dengan baik, efektif dan efisien, (2) Mengukur hasil pemasaran berdasarkan standard prestasi yang berlaku, tanpa adanya pembukuan yang jelas maka perusahaan tidak bisa mengukur nilai penjualan apakah naik atau turun, (3) Memberikan dasar yang logis dalam setiap pengambilan keputusan, dengan data hasil penjualan maka perusahaan dapat menetapkan strategi yang akan ditetapkan. Apakah akan menambah atau mengurangi produksi, atau keputusan strategis lain, (4) Mampu meningkatkan kemampuan dalam beradaptasi jika ada perubahanperubahan dalam pemasaran. Karena dunia pasar sangat dinamis, karena itulah perlu dibentuk strategi marketing yang tepat dengan integrasi terhadap divisi perushaaan yang lain (Anonim,2019).

\section{B. METODE PENELITIAN}

Analisis yang digunakan dalam penelitian ini adalah jenis analisis SWOT (Strenght, Weaknesses, Opportunities, Threats). Dan analisis ekonomi usaha yang ingin direncanakan yang terdiri dari analisis harga pokok produksi,analisis harga jual, analisis keuntungan, analisis kelayakan, serta analisis $\mathrm{BEP}($ break even point $)$, serta dengan menggunakan strategi pemasaran.

\section{a. Analisis $S W O T$}

SWOT adalah singkatan dari kata-kata Strength (kekuatan perusahaan) Weaknesses (kelemahan perusahaan), Opportunities (peluang bisnis) dan Threats (hambatan untuk mencapai tujuan). Analsis SWOT digunakan untuk melihat kekuatan, kelemahan, peluang dan ancaman yang akan dihadapi oleh perusahaan. Dengan melihat kekuatan yang dimiliki serta mengembangkan kekuatan tersebut dapat dipastikan bahwa perusahaan akan lebih maju dibanding pesaing yang ada.

\section{b. Analisis Ekonomi usaha. \\ Harga Pokok Produksi}

$\mathrm{HPP}=$ (Biaya Operasional + penyusutan alat 4 bulan)

$$
\text { Jumlah produk }
$$

\section{Harga}

$50 \%$

Harga jual $=$ Harga Pokok + keuntungan

Keuntungan

Ratio $=\mathbf{R} / \mathbf{C}$

Keuntungan $=$ pendapatan - biaya produksi

\section{c. Strategi Pemasaran}

Strategi pemasaran adalah salah satu cara memenangkan keunggulan bersaing yang berkesinambungan baik itu untuk perusahaan yang memproduksi barang atau jasa. Strategi pemasaran dapat dipandang sebagai salah satu dasar yang dipakai dalam menyusun perencanaan perusahaan secara menyeluruh. Dipandang dari luasnya 
permasalahan yang ada dalam perusahaan, maka diperlukan adanya perencanaan yang menyeluruh untuk dijadikan pedoman bagi segmen perusahaan dalam menjalankan kegiatannya.

\section{HASIL DAN PEMBAHASAN}

\section{a. analisis SWOT}

Analisis SWOT adalah sebuah teknik strategi dalam mengevaluasi kekuatan, kelemahan, peluang serta ancaman yang hal ini dapat diterapkan untuk kegiatan meliputi bisnis dan usaha, pendidikan, proyek atau bahkan pada diri sendiri.

Metode analisis SWOT bisa dianggap sebagai metode analisis yangg paling dasar, yang bermanfaat untuk melihat suatu topik ataupun suatu permasalahan dari 4 empat sisi yang berbeda. Hasil dari analisa biasanya berupa arahan ataupun rekomendasi untuk mempertahankan kekuatan dan untuk menambah keuntungan dari segi peluang yang ada, sambil mengurangi kekurangan dan juga menghindari ancaman. Jika digunakan dengan benar, analisis ini akan membantu untuk melihat sisi-sisi yang terlupakan atau tidak terlihat selama ini. Dari pembahasan diatas tadi, analisis SWOT merupakan instrumen yang bermanfaat dalam melakukan analisis strategi. Analisis ini berperan sebagai alat untuk meminimalisasi kelemahan yang terdapat dalam suatu perusahaan atau organisasi serta menekan dampak ancaman yang timbul dan harus dihadapi

Adapun analisis SWOT pada usaha BSR (Bio Solid Rubber) sebagai berikut :

\section{- $\quad$ Strenght (kekuatan) produk}

Streng yaitu analisis kekuatan, situasi ataupun kondisi yang merupakan kekuatan dari suatu perusahaan pada saat ini. Yang perlu di lakukan di dalam analisis ini adalah setiap perusahaan perlu menilai kekuatan-kekuatan dan kelemahan di bandingkan dengan para pesaingnya.

Adapaun kekuatan pada produk $B S R$ ini adalah:

1. Bahan baku mudah untuk didapatkan dan mudah untuk dibudidayakan jadi produsen tidak akan kesulitan untuk mendapatkan bahan bakunya

2. Menggunakan bahan baku alami sehingga ini sangat berdampak positif terhadap kondisi lingkungan. Juga tidak berbahaya bagi pengguna jika menggunakan produk $B S R$ ini
3. Harga yang ramah di kantong dibandingkan dengan bahan produk pengental karet berbahan kimia pada umumnya

\section{- Weaknesses (kelemahan)}

Weaknesses yaitu analisi kelemahan, situasi ataupun kondisi yang merupakan kelemahan dari suatu perusahaan pada saat ini. Merupakan cara menganalisis kelemahan di dalam sebuah perusahaan ataupun organisasi yang menjadi kendala yang serius dalam kemajuan suatu perusahaan.

Adapun kelemahan darp produk BSR ini adalah:

1. Belum banyak yang mengetahui produk $B S R$ ini, untuk itu kami harus melakukan cara promosi terlebih dahulu terhadap produk baru ini guna untuk mengenalkan jenis produk $B S R$ ini kepada masyarakat khususnya kepada para petani karet

\section{- Opportunities (peluang)}

Opportunities yaitu analisis peluang, situasi atau kondisi yang merupakan peluang diluar suatu perusahaan dan memberikan peluang berkembang bagi organisasi dimasa depan. Cara ini adalah untuk mencari peluang ataupun terobosan yang memungkinkan suatu perusahaan bisa berkembang di masa yang akan depan atau masa yang akan datang

Adapun peluang pada produk BSR ini adalah:

1. Cukup banyaknya masyarakat yang berprofesi sebagai petani karet di Indonesia. Ini suau hal yang bagus karena bisa sangat berpeluang untuk dijadikannya usaha

2. Produk dapat diperjual-belikan memalui media online maupun offline. Melihat masyarakat sekarang banyak yang paham tentang media sosial maka penjualan bisa dilakukan secara online, ini juga dinilai lebih praktis serta bisa mengefisiensikan waktu.

3. Penjualannya isa dipasarkan langsung kepada petani

\section{- Threats (Ancaman)}

Threasts yaitu analisis ancaman, cara menganalisis tantangan atau ancaman yang harus dihadapi oleh suatu perusahaan ataupun organisasi untuk menghadapi berbagai macam faktor lingkungan yang tidak menguntungkan pada suatu perusahaan atau organisasi yang menyebabkan kemunduran. Jika tidak segera di atasi, ancaman 
tersebut akan menjadi penghalang bagi suatu usaha yang bersangkutan baik di masa sekarang maupun masa yang akan datang.

Adapun ancaman pada produk $B S R$ ini adalah:

1. Memiliki pesaing namun tidak terlalu dikhawatirkan dapat mengancam usaha ini, dikarenakan produk pesaing lainnya berbahan dari kimia yang akan membahayakan bagi penggunanya

\section{b. Analisis Ekonomi usaha}

\section{Harga Pokok Produksi}

harga pokok produksi adalah akumulasi dari biaya yang dikeluarkan untuk menghasilkan produk dan kemudian dibebankan pada produk

Untuk menetukan harga pokok produksi (hpp) itu sendiri bisa di lakukan dengan cara:

$\mathrm{HPP}=($ Biaya Operasional+ penyusutan alat 4 bulan)

$$
\begin{aligned}
& \text { Jumlah produk } \\
& =\frac{3.850 .000+250.000}{700}
\end{aligned}
$$$$
=\text { Rp. 5.857,14 Harga jual }
$$

Harga jual yang diberikan untuk satu produk BSR (Bio Solid Rubber) adalah :

Sebelum menetukan harga jual produk hal yang harus dilakukan yaitu mengetahui berapa keuntungan yang ingin di dapatkan. Untuk penjualan produk ini kami mengambil keuntungan yang diinginkan sebanyak $50 \%$

Itu berarti cara menghitungnya dilakukan dengan cara seperti ini:

$$
\begin{aligned}
& =50 \% \times 5.857,14 \\
& =\text { Rp. } 2.928,57
\end{aligned}
$$

Untuk menetukan harga jual 1 botol Produk digunakan cara yaitu: diinginkan

Harga jual

$=$ Harga Pokok + keuntungan yang

$=$ Rp. $5.857,14+$ Rp. $2.929,57$

$=$ Rp. $8.785,71$

$=$ Rp. 9.000

Dengan harga Rp. 9.000 per produk BSR dengan ukuran $300 \mathrm{ml}$, tentunya ini sangat ramah dikantong jika dibandingkan dengan produk kimia yang biasa dijual dan mempunyai bahaya bagi penggunanya

Jadi untuk penjualan selama 4 bulan:

$=$ Rp. $9.000 \times 700$

= Rp. 6.300 .000

Keuntungan
Untuk mengetahui berapa keuntungan yang akan didapatkan digunakan cara:

Keuntungan $=$ pendapatan - biaya produksi

$$
\begin{aligned}
& =\text { Rp. } 6.300 .000-\text { Rp. } 3.850 .000 \\
& =\text { Rp. } 2.450 .000
\end{aligned}
$$

\section{Kelayakan Usaha}

Pada dasarnya sebuah proyek akan dikatakan layak untuk dijalankan apabila nilai R/C yang didapatkan lebih besar daripada 1 . Hal ini terjadi karena semakin tinggi nilai $\mathrm{R} / \mathrm{C}$ dari sbuah proyek, maka tingkat keuntungannya yang akan didapatkan suatu proyek juga akan semangkin tinggi.

Untuk mencari ratio itu sendiri di hitung dengan rumus:

$$
\begin{aligned}
\mathrm{R} / \mathrm{C} & =\text { Penerimaan Total } / \text { Total Biaya } \\
& =6.300 .000 / 3.850 .000 \\
& =1,63 \\
& \text { Jika } \mathrm{R} / \mathrm{C}>1,
\end{aligned}
$$

Didapatkan bahwa $\mathrm{R} / \mathrm{C}$ nya lebih dari satu, maka usaha ini dikatakan layak untuk dijalankan

\section{c. Strategi Pemasaran}

Strategi pemasaran adalah segala upaya yang dilakukan oleh perusahaan untuk mencapai target penjualan yang telah ditentukan.

Membuat rancangan strategi adalah hal yang mutlak dilakukan oleh perusahaan karena menjadi penentu nilai ekonomi dari perusahaan tersebut

Adapun langkah Strategis Pemasaran dalam usaha BSR ini yaitu dengan cara Perencanaan pemasaran yang akan dilakukan dalam pengenalan produk dilakukan melalui :

1. Strategi Produk

Produk BSR terbuat dari bahan baku yang sangat mudah untuk didapatkan di daerah Kecamatan Kuala, kabupaten Langkat karena pembuatan usaha ini masih dekat dengan daerah penjualan bahan baku maka usaha ini tidak akan memakan biaya transportasi yang lumayan banyak. Serta jenis tumbuhan ini gampang untuk tumbuh dimana saja. Selain itu bahan baku ini sangat mudah untuk dibudidayakan. Selain mudah untuk dibudidayakan jenis tanaman ini sangat jarang sekali di gunakan oleh masyarakat.

\section{Strategi Harga}

Harga yang kami tetapkan sesuai dengan keadaan konsumen(petani karet) dan harga yang ditawarkan terjangkau karena harga hanya berbeda sedikit saja dengsn jenis bahan kimia yang biasa mereka gunakan untuk mengentalkan getah karetnya.

3. Strategi Tempat 
Untuk tempat penjualannya kami akan membuka tokoh untuk menjual produk $B S R$ ini. Tempat penjualan untuk produk $B S R$ ini akan dibuka di sekitaran tempat tinggal petani karet yang ada di daerah Langkat

4. Strategi Promosi

Promosi yang digunakan dengan metode iklan dan promosi penjualan. bentuk iklan yang direncanakan adalah dengan cara menyebarkan brosur serta promosi secara online dengan cara membuat akun media social berupa facebook dan instagram.

\section{KESIMPULAN DAN SARAN}

\section{Kesimpulan}

1. Dari hasil analisis SWOT yang dilakukan, diketahui bahwa strength (kekuatan) dan opportunities (peluang) dari produk ini jauh lebih besar jika dibandingkan dengan weaknesses (kelemahan) dan threats (ancaman) maka usaha BSR ini memiliki peluang besar untuk di lakukan

2. Dari hasil perhitungan pada analisis ekonomi yang dilakukan diketahui bahwa usaha BSR ini layak untuk dilakukan karena diketahui bahwa $\mathrm{R} / \mathrm{C}=>1$ ( maka usaha ini layak )

3. Adapun strategi pemasaran yang digunakan untuk produk $B S R$ ini yaitu strategi produk, strategi harga, strategi tempat, dan strategi promosi. Strategi pemasaran ini terbukti mampu untuk membantu produk $B S R$ ini menjadi usaha yg berkelanjutan.

\section{Saran}

1. Diharapkan penelitian ini dapat digunakan sebagai referensi sekaligus bahan bacaan bagi petani yang bermasalah dalam proses pengentalan getah karetnya sekaligus untuk meningkatkan kualitas dan kuantitas getah karetnya.

2. Diharapkan peneliti selanjutnya dapat menggunakan jenis buah lainnya yang mengandung asam sebagai bahan pengental getah karet yang dapat meningkatkan kualitas getah karet.

\section{DAFTAR PUSTAKA}

Anonim,2019. Diakses pada tanggal 24 Mei 2019 darigoogle.

Website:https://rocketmanajemen.com/ tujuan-strategi-pemasaran/

Big, 2010. Diakses pada tanggal 20 Mei 2019 dari google.Website:http://www.big.go.id/b eritasurta/show/big- serahkan-petankri-kepada-kemenkokesra

Chusna SF, Zulfia V, Fahroji. 2017. Pengaruh Berbagai Jenis Pembeku Terhadap Pembekuan Lateks.Prosiding Seminar Nasional Subobtimal 2017.19-20 Oktober 2017,Palembang, Indonesia. Hal. 745-752

Hardiyanti R, Suheri AH, Ali F. 2013. Pemanfaatan Sari Mengkudu sebagai Bahan Penggumpal Lateks. Jurnal teknik Kimia. 19 (1): 54-59

Lestari F, Febrianti Y, Wiyono J. 2018. Pemanfaatan Sari Pati Umbi Gadung (Dioscorea hispida Dennst) Untuk Koagulasi Lateks Karet Alam (Hevea brasiliensis). Jurnal ilmiah biologi.6(1): 23-27

Rahayu M. 2011. Analisis Penentuan Metode Peramalan Penjualan (Sales Forecast) Terhadap Penyusunan Anggaran Penjualan Lateks Pekat dan Rubber Smoke Sheet (RSS) Pada PT Huma Indah Mekar Tulang Bawang. Jmk 9(1): 1-30

Risky R. 2011. Diakses pada tanggal 24 Mei 2019 darigoogle. Website: https://riskyridhaagriculture.blogspot.com

Sabarman D.2012. Pengembangan Karet (Hevea brasiliensis) Berkelanjutan di Indonesia. Jurnal persfektif. 11( 1): 91102

Susanto T, Prasetya H A. 2016.Kajian Penggunaan Pati Umbi Gadung Termodifikasi Sebagai Subsituen Carbon Pada Pembuatan Vulkanisat karet Alam. Jurnal Dinamika Penelitian Industri.27(2): 82-93

Syarifa L F.2014. Studi Kelayakan Investasi Pembangunan Perkebunan karet di Sumatera Selatan. Jurnal penelitian Karet 32(2): 148-156 